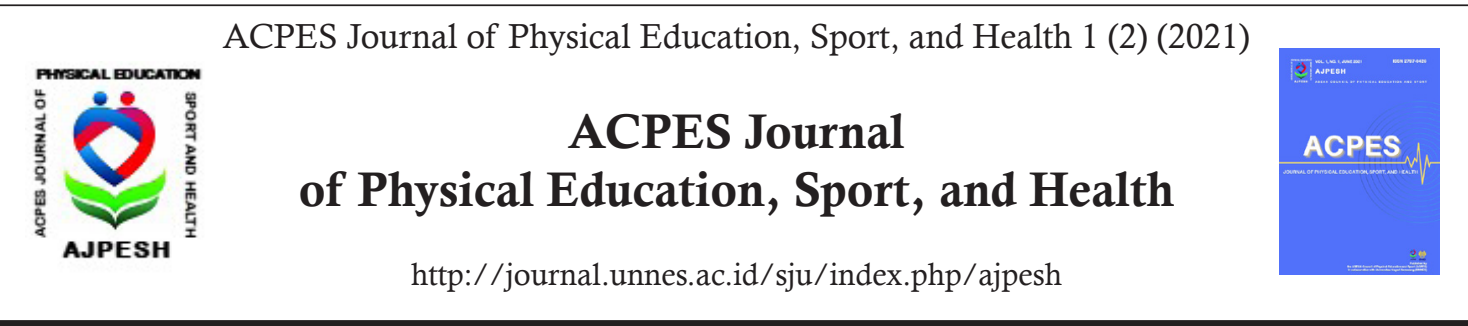

\title{
Optimization of the Application of Inclusive Teaching Style in Im- proving Learning Outcomes Forehand Push Table Tennis Game in Class XI IPA 1 Private Senior Highschool PAB Saentis
}

\author{
Devi Catur Winata ${ }^{\bowtie}$, Andy Nur Abadi, Filli Azandi, Mhd Fahmi, Bahder Johan Hara- \\ hap
}

Sekolah Tinggi Olahraga dan Kesehatan Bina Guna, Indonesia

DOI: https://doi.org/10.15294/ajpesh.v1i2.49164

\begin{tabular}{l} 
Article Info \\
\hline Article History \\
Submitted 2021-08-16 \\
Revised 2021-09-29 \\
Accepted 2021-11-17 \\
Keywords \\
forehand push learning \\
outcomes, inclusive teach- \\
ing style, senior high school
\end{tabular}

\begin{abstract}
This study aims to find out how to improve learning outcomes of Forehand Push table tennis game through inclusive teaching style in class XI IPA 1 Private Senior Highschool PAB SAENTIS. The object of this research is class XI students with 25 students who will be given action in the form of inclusive teaching style on Forehand Push learning outcomes. In the first cycle, it could be seen that the students' initial ability to perform the Forehand Push technique was still low. Of the 25 students there are 15 people $(60 \%)$ who have achieved mastery learning, while 10 people (40\%) have not achieved mastery learning. With the average value of student learning outcomes is 76.3. Meanwhile, in the second cycle, it can be seen that the students' ability to perform classical learning outcomes tests has increased. Of the 25 students there are $20(80 \%)$ who have achieved mastery learning, while 5 people $(20 \%)$ have not achieved mastery learning. With the average value of student learning outcomes is 80.7 , so there is a $25 \%$ increase in learning outcomes from cycle I to cycle II. It can be concluded that learning through inclusive teaching style can improve forehand push learning outcomes in class XI IPA 1 Private Senior Highschool PAB SAENTIS.
\end{abstract}

\section{INTRODUCTION}

Education is one of the most important things to equip students to face the future. For this reason, a meaningful learning process will determine the realization of quality education. Students need to be given adequate guidance, encouragement, and opportunities to study and learn the things that are needed in their lives. Physical education is education that uses physical activity as the main medium to achieve goals, the forms of physical activity used by students are forms of sports movement so that the physical education curriculum in schools includes sports (Winata et al., 2021).

In the game of badminton there are several basic techniques, namely: 1). Racket Holding Techniques, 2). Punch Technique. A service is a stroke that starts or serves the first ball as the start of the game. In the technique of hitting (service) there is one stroke technique, namely Backhand Overhead. In general, in this material, students are very difficult to interpret the stimulus given by the teacher. Because the Backhand Overhead punch has a level of difficulty compared to the Overhead forehand punch technique or others (Setiawan et al., 2015; Sheng et al., 2020). Because the Overhead backhand stroke is done by extending the dominant hand completely towards the top of the player's field Overhead backhand angle and is the opposite of the Overhead forehand shot, therefore, the Over-

Correspondence Author:

J1. Rumah Potong Hewan No. 95 a Keluarahan Mabar

e-ISSN 2797-0426

Kecamatan Medan Deli, Kota Medan Prov Sumatera Utara

E-mail: devicatur25@gmail.com 
head backhand stroke is not only difficult and requires good teacher guidance in the learning process to improve student learning outcomes (Alexandros et al., 2013).

In improving learning outcomes of backhand strokes, the teacher's role is definitely needed in providing a stimulus to students through learning methods applied by physical education teachers, because the application of learning methods greatly affects student learning outcomes. Because in this era of globalization, students are accustomed to learning from what they see, hear, and so on. So, if the physical education teacher does not master other teaching styles/learning methods, it will make students more bored in participating in learning (Tohaya, 2013).

From the results of a survey conducted at PAB SAENTIS Private Senior Highschool, students are less interested in taking badminton lessons because they think that badminton lessons are not interesting, and it can also be seen that the motivation that exists from within the students is very less to take badminton lessons. In this school, almost all physical education lessons conducted by teachers use the commando teaching style and do not use other teaching styles. Students only follow and carry out what the teacher says. So that students are less creative in the learning process and teachers are less able to improve students' thinking skills. The facilities and infrastructure at the school also do not support the teaching and learning process because the badminton court at the school does not meet the standards. Then student learning outcomes also show low numbers, where students who enter the "complete" category in the KKM are only a few, and the "incomplete" category of students dominates.

Then, the problems found by researchers after initial observations and seeing the value of student learning outcomes in the sub-competence of mastering basic forehand push strokes in badminton games, it was found that only a few students who could do forehand pushes in badminton games only some students or approximately $30 \%$. And the rest who still can't do forehand push well. The results obtained are very low so that researchers are trying to fix the problems found in this class. Mistakes that often occur include forehand push made with small mistakes such as foot posture, body posture and even the wrong hand position of students.

According to Kertamanah (2013:52), "Push punch is a pushing punch that is used for the middle distance". According to Damiri \& Kusmedi (2019:59), "Push is a technique of hitting the ball with a pushing motion, with an open bet attitude". Meanwhile, according to Sutarmin (2007: 27), "Push is the movement of the bet, the movement of hitting the ball that comes from the opponent's direction is pushed with a bet with an open bet position". So from the above understanding it can be concluded that a push punch is a pushing punch with an open bet position that is used for mid-range shots.

Sridadi et al. (2012), say that the purpose of this style Inclusion is to teach students at the level of each ability, each student is required to be involved in this learning process, because students can choose activities that they think they are capable of doing.

\section{METHOD}

In every research in science generally aims to find and develop and test the truth of a science. The research method is the method used by researchers to achieve certain goals and objectives. The research method used in this research is Classroom Action Research.

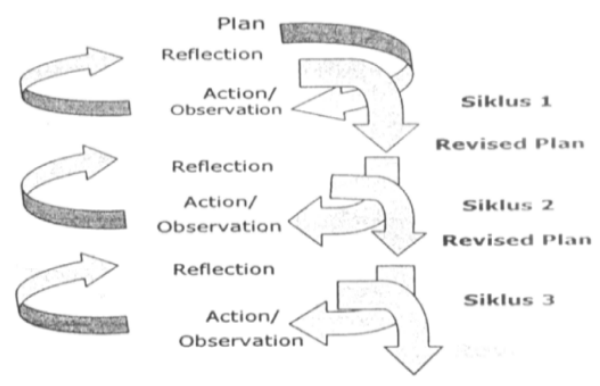

Figure 1. Research Design

Kristiyanto (2010: 19)

The assessment aspect in the form of a score obtained from each item is adjusted based on the 
criteria that have been made, where the highest total score is 3 and the lowest is 1 , and the maximum total score for all items is 12 , as seen in the Table 1 .

The learning outcomes test aims to determine whether students' forehand push learning outcomes in table tennis games will increase after being taught through the inclusive teaching style.

Table 1. Portfolio of forehand push results.

\begin{tabular}{|c|c|c|c|}
\hline \multirow[t]{2}{*}{ Picture } & \multirow[t]{2}{*}{ Indicator } & \multirow{2}{*}{ Descriptor } & Score \\
\hline & & & Check Mark \\
\hline & Preparation phase & $\begin{array}{l}\text { 1. Left foot in front } \\
\text { 2. The body position is tilted to the rightand the knees are bent } \\
\text { 3. Bet is in a sliphtly backward position } \\
4 \text { Bet head facing the eround with arms down. }\end{array}$ & \\
\hline & Implementation Phase & $\begin{array}{l}\text { 1. When the ball is heading towards the player, the arm is swume } \\
\text { forward by swipingat the back of the ball } \\
\text { 2. The postion of the left hand balances the body and increases the } \\
\text { strength of the thrust } \\
\text { 3. Fush the wrist when the ball goes to the player, the bet position } \\
\text { leads to the arrival of the ball by openingit up } \\
\text { 4. The movement of the lower hand is open and the head of the bet } \\
\text { follows themovement }\end{array}$ & \\
\hline & Follow Through Phase & $\begin{array}{l}\text { 1. The bet follows the contact area pointing downward parallel to the } \\
\text { return of the ball } \\
\text { 2. Push your body forward with your back foot } \\
\text { 3. Weight shifts from back to front } \\
\text { 4. Swing the back leg ina scissor-like motion }\end{array}$ & \\
\hline
\end{tabular}

(Source Sutarmin, 2017). Information : Check if the descriptor appears and is done by the student, Put a cross if it doesn't appear,Sum the checks that appear for the highest number of values

\section{RESULTS AND DISCUSION}

\section{Preliminary data}

This research was carried out in the field of PAB SAENTIS Private Senior Highschool. Before the research is conducted, the researcher first conducts initial data which aims to see and formulate the problems obtained from the results of the initial data carried out. The test given to students is in the form of a forhand push learning result test in badminton lessons which is carried out before determining the plan.

Table 2. Description of Initial forehand push

\begin{tabular}{cccc}
\hline Test Result & $\mathrm{f}$ & Percentage & Category \\
\hline Score $<74$ & 20 & $80 \%$ & Incomplete \\
Score $>75$ & 5 & $20 \%$ & Complete \\
\hline
\end{tabular}

Based on the table description of the Preliminary Data forehand push, it can be seen that the students' ability in learning forehand push has not reached the specified KKM value. Of the 25 students who became subjects in this study, it turned out that only 5 students $(20 \%)$ had mastery learning, while the remaining 20 students $(80 \%)$ did not yet have learning mastery. With the average value of student learning outcomes is 70

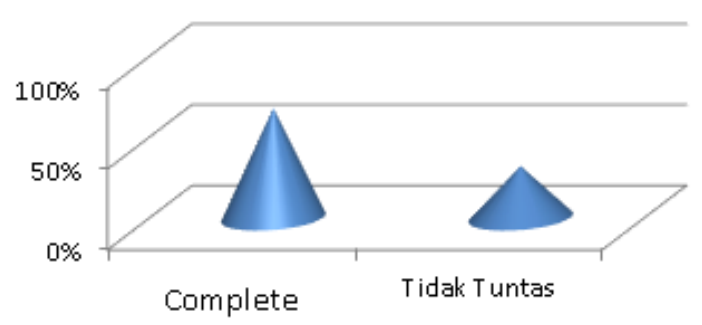

Figure 2. Initial Data Description forehand push

Based on the description that has been described above, there are several weaknesses, namely learning is dominated by the teacher, because there are no games or games that support the subject 
matter, so there is a lack of communication between students and teachers and students with students, so this can lead to boredom in students. As a result, most students are passive in participating in learning, so that ultimately causes low student learning outcomes. Thus, the learning carried out can be said to be ineffective.

\section{Description of cycle I}

\section{a. Planning stage}

Before carrying out the action activities, the researcher made a learning design designed by the researcher in collaboration with the teacher. The learning design designed by the researcher follows the learning design format quoted from the syllabus development book through a competition-based curriculum developed by the Ministry of National Education which is then adapted to the curriculum developed by the school and the learning methods used. The design is made based on the results of observations of initial data in the learning process of physical education, sports and health, especially forehand push material

b. Action implementation stage

In this stage the researcher and the implementing teacher carry out learning by applying the inclusive teaching style by using several forms of exercises that have been prepared to support forehand push learning outcomes. With the main discussion of the attitude of holding the racket, the attitude of the beginning, the attitude of implementation, the final movement which in its implementation is packaged into audio-visual form, namely by 1) interaction between the teacher and students, 2) Students discussing forehand push material, 3) Students practicing the forehand push movement. This activity is carried out repeatedly with teacher demonstrations about forehand push.

a) Initial activities

For apperception the teacher coordinates the class and then continues with activities in the form of habituation of moral attitudes, religion, which consists of being in line, praying, greeting and taking attendance. Questions and answers were conducted by the teacher to determine the students' prior knowledge. Furthermore, the teacher conveys the main material being studied and informs the basic competencies and learning objectives that students want to achieve in the first action plan, namely:

1. Prepare Lesson Plans (RPP) using the inclusive teaching style

2. Planning the learning steps and launching the inclusive teaching style until they finally succeed in finding and solving problems and achieving the learning objectives to be achieved.

3. Prepare for the first cycle of learning outcomes test.

Then after the action was given for 35 minutes and students were given a forehand push cycle I test for 15 minutes. Teachers and collaborators assess the course of the test by assessing according to the assessment indicators that have been provided.

c) Final / closing activities

The teacher gives a cooling down (colling down) in the form of light movements, namely: the children form 2 rows with a distance of one arm, the sons and daughters are separated, then both hands hold the shoulders of their friends in front of them and do a slow massage. Then turning right does the same thing, the next movement hits with fingers close to the shoulder to the back with a slow stroke, then turning right does the same thing. Then students sit quietly listening to the teacher's directions.

c. Cycle I . test and observation

From observations on the implementation of the actions in cycle I, during the learning activities, researchers and collaborators observed the course of the activities through observation to see whether these actions were in accordance with the plan, how were the learning outcomes of forehand push after being given action, through the application of the inclusive teaching style was in accordance with expected or not in order to be able to continue and correct the next research.

The evaluation results obtained by students in cycle 1 learning are presented in the form of tables and histogram graphs as follows: 
Devi Catur Winata et al. / AJPESH 1 (2) (2021)

Table 3. Distribution of Learning Results Forehand Push Cycle I

\begin{tabular}{cccc}
\hline Score & $\mathrm{f}$ & $\%$ & $\mathrm{~S} \mathrm{X} \mathrm{F}$ \\
\hline $58.0-65.0$ & 2 & $8 \%$ & 116 \\
$66.0-74.0$ & 8 & $32 \%$ & 528 \\
$75.0-82.0$ & 10 & $40 \%$ & 750 \\
$83.0-93.0$ & 5 & $20 \%$ & 415 \\
Total & 25 & $100 \%$ & 1809 \\
\hline
\end{tabular}

Based on the table above, it can be concluded that as many as 15 students completed or about $60 \%$ with a minimum limit of 75 of 25 students. While students who did not complete about 10 students or about $40 \%$ for a clearer view of the histogram below:

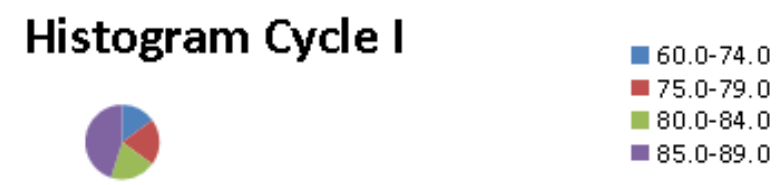

Figure 3. Histogram cycle I Evaluation Result Forehand Push

We can see in the graph above shows that the vulnerable value of 58-65 there are about 2 students, the range of values of 66-74 is about 8 students and the vulnerable value of $75-82$ is about 10 students and the range of values between $83-92$ is 5 students so that there are 15 students who reach the KKM target so that only about $60 \%$ classically complete students, so it is necessary to do a second cycle to achieve $85 \%$ classical grades and completeness.

e. Action reflection cycle I

After carrying out learning activities and calculating research data, teachers and observers reflect and discuss problems related to the actions taken by the teacher. Seen in the first cycle there are still many shortcomings both from the teacher and from the students.

3. Description of cycle II

a. Planning stage

In the second cycle, the learning activities were carried out according to the plans discussed by the implementing teachers, collaborator teachers and researchers. Because as we have seen in the first cycle there are still many students who do not understand how to throw and reject bullets so that during the implementation there are some students who always receive punishment for not being able to Forehand Push properly. After careful attention, this happens because students move statically during Forehand Push so that many students are not ready and are not able to master Forehand Push.

b. Implementation stage

In the second cycle, it was held on Wednesday, June 2021 learning activities started at 09.0011.00 WIB which consisted of initial activities, core activities and closing activities. In the second cycle, students are expected to be able to carry out activities as expected. Students can enjoy and be able to carry out activities as well as possible and can improve learning outcomes for Forehand Push.

a) Preliminary activities

In this initial activity, as usual, the teacher appreciates the teacher conditioning the class, then continues with the habituation of moral attitudes and behavior

b) Core activities

Core I the teacher uses the inclusive learning method. Students learn after those students are lined up in the field to do the Forehand Push movement that has been observed before, students do repetitive movements.

c) Closing activities

The teacher gives a cooling down (colling down) in the form of light movements, namely: the children form 2 rows with a distance of one arm, the sons and daughters are separated, then both hands hold the shoulders of their friends in front of them and do a slow massage.

c. Forehand Push learning result data in cycle II

The application of this teaching style turned out to be effective in improving the learning outcomes of Forehand Push in class XI PRIVATE SENIOR HIGHSCHOOL PAB SAENTIS SENIOR 
HIGHSCHOOL . It is proven in the following table of student learning outcomes with a significant increase in learning outcomes from the previous one

Table 4. Distribution of Forehand Push Learning Outcomes Cycle II

\begin{tabular}{cccc}
\hline Score & $\mathrm{f}$ & $\%$ & $\mathrm{~S} \mathrm{X} \mathrm{F}$ \\
\hline $66.0-74.0$ & 5 & $20 \%$ & 330 \\
$75.0-79.0$ & 5 & $20 \%$ & 375 \\
$83.0-92.0$ & 15 & $60 \%$ & 1275 \\
Total & 25 & $100 \%$ & 1980 \\
\hline
\end{tabular}

Based on the table above, we can conclude that the students who completed were 20 students or about $80 \%$ with a minimum score of 75 , and the students who did not complete were about 5 students or about $20 \%$ which can be seen from the histogram graph below:

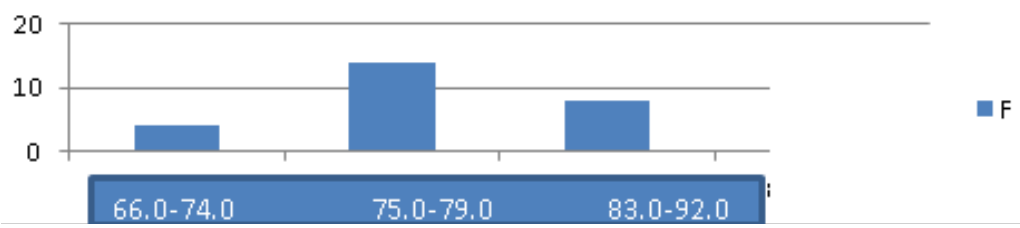

Figure 4. Histogram Graph of Cycle II Learning Outcomes Forehand Push

From the histogram graph above, it shows that Forehand Push learning outcomes are very significant from the previous histogram graph, that the range of values between 66.0-74.0 there are 5 students who did not complete the scores obtained did not reach the specified target, while the range of values between 75.0-79.0 were 5 students, vulnerable students' scores and vulnerable scores between 83.0-92.0 there are 15 students so that in total there are 20 students who have reached the KKM score and classically the number of students completeness is $80 \%$ so the cycle stops here.

\section{CONCLUSION}

There is an increase in student learning outcomes through the inclusive teaching style of Forhand Push Table Tennis material for class XI students of PAB SAENTIS PRIVATE SENIOR HIGHSCHOOL.

\section{ACKNOWLEDGEMENT}

This research was funded by the STOK Bina Guna foundation. This research was conducted with 6th semester students who entered the table tennis course, students helped in this research and lecturers outside of the writing team also helped in the success of this research.

\section{REFERENCES}

Alexandros, M., Christina, K., Nikolaos, G. \& Konstantinos, M. 2013. Effectiveness of Backhand with One and Two Hands in Teaching Adult Men Beginners in Tennis. Journal of Physical Education and Sport, 13 (3): 415-418. https://efsupit.ro/images/stories/66.pdf

Damiri, A. \& Kusmedi, N. 2010. Olahraga Pilihan Tenis Meja. Jakarta: Departemen Pendidikan dan Kebudayaan, Direktorat Jenderal Pendidikan Tinggi, Proyek Pembinaan Tenaga Kependidikan.

Dinas Olahraga dan Pemuda DKI Jakarta. 2010. Petunjuk Permainan Tenis Meja. Jakarta: Dinas Olahraga dan Pemuda DKI Jakarta.

Kertamanah, A. 2013. Teknik dan Taktik Dasar Permainan Tenis Meja. Jakarta: Raja Grafindo

Kristiyanto, A. 2010. Penelitian Tindakan Kelas (PTK) Dalam Pendidikan Jasmani dan Kepelatihan Olahraga. Surakarta: Sebelas Maret University Press. https://digilib.uns.ac.id/dokumen/download $/ 30804 / \mathrm{NjQ} 4 \mathrm{Mzk}=/$ Penelitian-Tindakan-Kelas-PTK-dalam-pendidikan-jasmani-dan- 
kepelatihan-olahraga-abstrak.pdf

Setiawan, P.P.H., Kaswari. \& Purnomo, E. 2015. Meningkatkan Teknik Forehand Tenis Meja Menggunakan Dinding Pantul Kelas VIII A SMP 11 Pontianak. Proceedings. https://media.neliti.com/media/ publications/214735-none.pdf

Sheng, W.Y., Ginanjar, A. \& Wei, G.T. 2020. The Effects of Teaching Badminton Practise on Improving Badminton Capabilities of Sports Department Students. European Journal of Molecular and Clinical Medicine, 7 (1): 3853-3866. https://ejmcm.com/pdf_4947_8aa2d1b833b379b510cd24c704c6c3e9. $\mathrm{html}$

Sutarmin. 2007. Terampil Berolahraga Tenis Meja. Surakarta: Era Intermedia.

Sridadi, Tomoliyus \& Utama, B. 2012. Kemampuan Bermain Tenis Meja Tingkat Pemula. Research Report. Yogyakarta: FIK Universitas Negeri Yogyakarta.

Tohaya. Upaya Meningkatkan Hasil Belajar Tenis Meja dengan Menggunakan Media Dinding pada Siswa Kelas V SDN 02 Jetak Kidul Kecamatan Wonoprogo Kabupaten Pekalongan Tahun Pelajaran 2012/ 2013. Undergraduated Thesis. Semarang: Universitas Negeri Semarang http://lib.unnes. ac.id/19465/1/6101911067.pdf

Winata, D.C., Syaleh, M., Munawar, A.A., Abady, A.N. \& Keliat, P. 2021. Smash Skill in Table Tennis Games (A Correlational Study of Speed Reaction, Explosive Power of Muscle Arm and Hand-Eye Coordination toward Students' Smash Skills of STOK Binaguna Medan. ACPES: Journal of Physical Education, Sport, and Health, 1 (1): 79-86. https://journal. unnes.ac.id/sju/index.php/ajpesh/article/view/46323 
Devi Catur Winata et al. / AJPESH 1 (2) (2021) 